\title{
GŁÓD JAKO PROBLEM EKONOMICZNY I SPOLECZNY W ŚWIETLE NAUCZANIA HOMILETYCZNEGO JANA CHRYZOSTOMA
}

Głód i niedobory żywności spowodowane m.in. wojnami, prymitywną gospodarką rolną oraz różnego rodzaju niekorzystnymi zjawiskami przyrodniczymi, takim jak susze, powodzie czy inwazje owadów ${ }^{1}$, były stałymi elementami towarzyszącymi ludziom epoki starożytnej². Jednak pomimo powszechności tych zjawisk, w starożytności istniały bardzo ograniczone metody i strategie zaradzaniu niebezpieczeństwu głodu ${ }^{3}$.

Głód w świecie starożytnym dotykał przede wszystkim ludzi z niższych warstw społecznych, którzy nie posiadali znaczniejszych zasobów bogactw ${ }^{4}$. Ludzie bogaci często unikali doświadczenia braku żywności w czasach gło$\mathrm{du}^{5}$, podczas gdy ubodzy byli pierwszymi jego ofiarami, gdyż środki materialne, którymi dysponowali, szybciej się uszczuplały i szybciej doświadczali też braku żywności, a w konsekwencji - głodu.

Niedobór żywności i głód wpływają nie tylko na kondycję fizyczną osób głodujących, lecz także na ich psychikę

${ }^{*}$ Ks. dr hab. Piotr Szczur, prof. KUL - kierownik Katedry Historii Kościoła w Starożytności i Średniowieczu w Instytucie Historii Kościoła i Patrologii na Wydziale Teologii Katolickiego Uniwersytetu Lubelskiego Jana Pawła II; e-mail: p_szczur@ kul.pl.

${ }^{1}$ Por. C. Strzeszewski, Głód, II. Aspekt społeczno-ekonomiczny, EK V 1144.

${ }^{2}$ Por. P. Garnsey, Responses to Food Crisis in the Ancient Mediterranean World, w: Hunger in History: Food Shortage, Poverty and Deprivation, ed. L.F. Newman, Cambridge (Mass.) 1990, 126; S.R. Holman, The Hungry Body: Famine, Poverty, and Identity in Basil's Hom. 8, JECS 7 (1999) 338; taż, The Hungry are Dying: Beggars and Bishops in Roman Cappadocia, Oxford - New York 2001, 67.

${ }^{3}$ Por. M. Jameson, Famine in the Greek World, w: Trade and Famine in Classical Antiquity, ed. P. Garnsey - C.R. Whittaker, Cambridge Philological Society. Supplementary Volumes 8, Cambridge 1983, 7.

${ }^{4}$ Por. K.S. Gapp, The Universal Famine Under Claudius, HTR 28 (1935) 258-265; S.W. Millman - R.W. Kates, Toward Understanding Hunger, w: Hunger in History, s. 12.

${ }^{5}$ Por. Joannes Chrysostomus, Ad populum Antiochenum hom. 2, 7, PG 49, 44, thum. J. Iluk: Św. Jan Chryzostom, Mowy do Antiocheńczyków o posagach, Gdańsk 2017, s. 32: „Jak się wydaje, bogactwo tylko w jednym przewyższa biedę, w tym, że pozwala każdego dnia cieszyć się i jeść do syta na biesiadach".

${ }^{6}$ Por. J. Strojnowski, Głód, EK V 1143. 
stawie wobec społeczeństwa, w którym funkcjonują ${ }^{7}$ Konsekwencją braku żywności i głodu (lub lęk przed nim) były rozruchy społeczne ${ }^{8}$, czy nawet przemieszczanie się całych społeczeństw. Wskazuje to na fakt, że głód może też mieć poważne konsekwencje polityczne. Głód i niedobory żywności są zatem ważnymi zjawiskami nie tylko ekonomicznym, ale i społecznymi, które godne są refleksji naukowej ułatwiającej zrozumienia starożytnego świata.

Problem głodu w świecie starożytnym był przedmiotem wielu badań ${ }^{9}$, które jednak należy uznać za cząstkowe. Przykładowo Peter Garnsey ${ }^{10}$ w swych analizach skupił się głównie na Atenach i Rzymie, co zauważa Susan R. Holman ${ }^{11}$ pisząc, że Garnsey nie omawia problemu głodu w Azji Mniejszej. Holman zatem wypełnia tę lukę badawczą i omawia problem głodu i nędzy w Kapadocji. Istnieją jednak obszary badawcze, które nie zostały jeszcze odpowiednio zbadane. Do nich należy m.in. spuścizna kaznodziejska Jana Chryzostoma ${ }^{12}$.

W niniejszym artykule zostanie przeanalizowany jeden, jednak niezwykle istotny problem świata antycznego, a mianowicie niedobór i brak żywności ${ }^{13}$. Skupimy się na tym, co Złotousty kaznodzieja mówi w swych homiliach na temat głodu jako zjawiska ekonomicznego i społecznego oraz ludzi głodnych obecnych w Antiochii ${ }^{14}$ i Konstantynopola ${ }^{15}$, dwóch wielkich aglomeracjach

\footnotetext{
${ }^{7}$ Por. Holman, The Hungry are Dying, s. 64.

${ }^{8}$ Por. B.W. Winter, Secular and Christian Responses to Corinthian Famines, „Tyndale Bulletin” 40 (1989) 86-106.

${ }^{9} \mathrm{Z}$ ważniejszych prac można wymienić: Trade and Famine in Classical Antiquity; C. Virlouvet, Famines et émeutes à Rome des origines de la République à la mort de Néron, Collection de l'École Française de Rome 87, Rome 1985; P. Garnsey, Famine and Food Supply in the GraecoRoman World, Cambridge 1988; tenże, Food and Society in Classical Antiquity, Cambridge 1999; D.Ch. Stathakopoulos, Famine and Pestilence in the Late Roman and Early Byzantine Empire: A Systematic Survey of Subsistence Crises and Epidemics, Birmingham Byzantine and Ottoman Monographs 9, Aldershot 2004.

${ }^{10}$ Por. Garnsey, Responses to Food Crisis in the Ancient Mediterranean World, s. 126-146.

${ }^{11}$ Por. Holman, The Hungry are Dying, s. 68.

${ }^{12}$ Wprawdzie istnieje niewielkie objętościowo opracowanie na temat głodu i niedoboru żywności w pismach Jana Chryzostoma, jednak trudno je uznać za kompletne opracowanie problemu; por. H. Stander, Chrysostom on Hunger and Famine, „Hervomde Teologies Studies” 67 (2011) 1-7. Na podstawie wypowiedzi kaznodziei Hennie Stander analizuje zjawisko głodu z kilku perspektyw: ekonomicznej (s. 1-2), socjalnej (s. 2-3), teologicznej (s. 3-4), filozoficznej (s. 4), medycznej (s. 4-5), egzegetycznej (s. 5) i humanitarnej (s. 5-6). Już z objętości poszczególnych części tekstu można wyciągnąć wniosek, że materiał źródłowy został potraktowany pobieżnie.

${ }^{13}$ Zaspokajanie głodu jest jedną z podstawowych potrzeb człowieka; por. Millman - Kates, Toward Understanding Hunger, s. 3.

${ }^{14} \mathrm{Na}$ gruncie polskim powstała obszerna monografia na temat Antiochii: P. Szczur, Problematyka społeczna w późnoantycznej Antiochii na podstawie nauczania homiletycznego Jana Chryzostoma, Lublin 2008.

${ }^{15} \mathrm{Na}$ gruncie polskim powstała obszerna praca na temat Konstantynopola: Konstantynopol - Nowy Rzym: miasto i ludzie w okresie wczesnobizantyńskim, red. M.J. Leszka - T. Wolińska, Warszawa 2011.
} 
starożytnych. Z tego też względu bazę źródłową niniejszego opracowania będą stanowiły homilie Jana Chryzostoma, które wygłosił jako prezbiter w Antiochii $^{16}$ i biskup w Konstantynopolu ${ }^{17}$.

1. Homilie jako źródła historyczne. Na wstępie należy zauważyć, że w związku z dobraną w niniejszym artykule bazą źródłową pojawiają się dwa podstawowe problemy metodologiczne. Po pierwsze, wykorzystywanie homilii jako źródła historycznego może budzić pewne wattpliwości związane z wartością przekazu kaznodziei. Po drugie, nie zawsze da się ustalić, czy jakieś kazanie zostało wygłoszone przez Chryzostoma w Antiochii, gdy był prezbiterem, czy w Konstantynopolu, gdy był biskupem ${ }^{18}$. Jednak wobec pierwszej wątpliwości należy jasno powiedzieć, że starożytne kazania i homilie są bardzo przydatne do poznania życia codziennego i doświadczeń ludzi ubogich danej epoki ${ }^{19}$. Wobec zaś drugiej wątpliwości trzeba stwierdzić, że dla zaprezentowanych poniżej analiz, nie ma ona większego znaczenia, gdyż

${ }^{16}$ Od końca 380 lub początku roku 381, Chryzostom był diakonem. Święceń udzielił mu biskup Melecjusz (por. Palladius, Dialogus de vita Iohannis Chrysostomi 5, 34, ed. A.M. Malingrey P. Leclercq, SCh 341, Paris 1988, 110; J.N.D. Kelly, Złote usta. Jan Chryzostom - asceta, kaznodzieja, biskup, tłum. K. Krakowczyk, Bydgoszcz 2001, 49; C. Tiersch, Johannes Chrysostomus in Konstantinopel (398-404). Weltsicht und Wirken eines Bischofs in der Hauptstadt des Oströmischen Reiches, Studien und Texte zu Antike und Christentum 6, Tübingen 2002, 60). Na prezbitera został wyświęcony na początku 386 r., lecz nie wcześniej niż 15 lutego. Odnośnie daty święceń zob. C. Baur, Johannes Chrysostomus und seine Zeit, t. 1: Antiochien, München 1929, 180; L. Brottier, Introduction, w: Jean Chrysostome, Sermons sur La Genèse, SCh 433, Paris 1998, 11; Kelly, Ztote usta, s. 49 i 65; Tiersch, Johannes Chrysostomus in Konstantinopel (398-404), s. 60-61.

${ }^{17}$ Według synaksarionu Konstantynopolitańskiego (Synaxarium ecclesiae Constantinopolitanae e codice Sirmondiano nunc Berolinensi, ed. H. Delehaye, w: Propylaeum ad Acta sanctorum Novembris, Bruxellis 1902, 312-313) Jan Chryzostom został biskupem 15 grudnia 397 r. Zaś według Sokratesa 26 lutego 398 r. (HE VI 2, 11, ed. G.C. Hansen, GCSNF 1, Berlin 1995, 313:

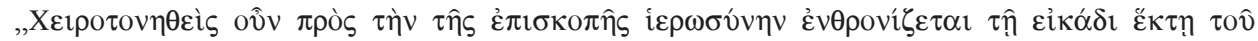

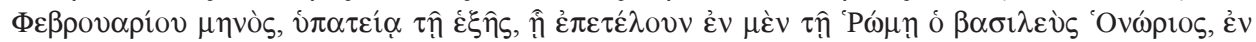

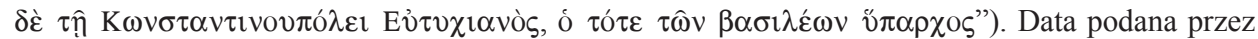
Sokratesa jest powszechnie przyjmowana [por. G. Dagron, Naissance d'une capitale. Constantinople et ses institutions de 330 à 451, Paris 1974, 464-465; Kelly, Złote usta, s. 117, gdzie w przekładzie polskim została błędnie podana data 26 stycznia $391 \mathrm{r}$. (por. z oryginałem, gdzie data jest poprawna: J.N.D. Kelly, Golden Mouth. The Story of John Chrysostom - Ascetic, Preacher, Bishop, Ithaca New York 1998, 106).

18 Fundamentalnym opracowaniem dotyczącym problematyki pochodzenia homilii Jana Chryzostoma jest monografia W. Mayer, The Homilies of St John Chrysostom: Provenance. Reshaping the Foundations, OCA 273, Rome 2005. Autorka sumuje dotychczasowe stanowiska, a na podstawie rozmaitych danych i kryteriów stara się wskazać miejsca wygłoszenia poszczególnych homilii. Zob. R. Finn, Almsgiving in the Later Roman Empire: Christian Promotion and Practice (313-450), Oxford 2008, 150; W. Mayer, John Chrysostom on Poverty, w: Preaching Poverty in Late Antiquity: Perceptions and Reality, ed. P. Allen - B. Neil - W. Mayer, Arbeiten zur Kirchen- und Theologiegeschichte 28, Leipzig 2009, 70-71.

${ }^{19}$ Por. Holman, The Hungry are Dying, s. 443. 
w artykule nie zajmujemy się przedstawianiem rozmiaru niedoboru żywności czy głodu w konkretnym mieście związanym z działalnością Jana Chryzostoma (Antiochia i Konstantynopol). Celem zaś artykułu jest ukazanie, poprzez pryzmat kazań Chryzostoma, jednej z ważnych kwestii ekonomicznych i społecznych IV w., a mianowicie problemu niedoboru żywności i głodu.

Mówiąc zaś o homiliach jako źródłach historycznych należy zauważyć, że do naszych czasów zachowały się tysiące starożytnych homilii, co wiele mówi o ich popularności w tym okresie i częstotliwości nauczania homiletycznego. Były one wygłaszane przez kaznodziejów Kościoła pierwotnego, którzy przez głoszone słowa starali się pouczyć słuchaczy na temat prawd wiary oraz zachęcić ich do dobrego życia. Nieraz czynili to w sposób bardzo żywiołowy i spontaniczny, np. opowiadając anegdoty i szeroko odwołując się do codziennych sytuacji życiowych, z którymi spotykali się odbiorcy ich kazań. To sprawia, że tego typu homilie swym stylem odbiegały od oficjalnej literatury kościelnej tego okresu. Wczesnochrześcijańskie homilie odzwierciedlają zatem sytuacje codziennego życia oraz ukazują religijne i społeczne myślenie zwykłych lu$\mathrm{dzi}^{20}$. Ponadto należy podkreślić, że w okresie wczesnego chrześcijaństwa homilia była głównym nośnikiem kultury i miała fundamentalne znaczenie dla przekazywania i kształtowania pewnych norm społecznych.

Dziwi zatem fakt, że tak bogaty materiał źródłowy nadal nie jest w pełni systematycznie eksplorowany. Chociaż jest wiele powodów takiego stanu rzeczy, to generalnie rzecz ujmując, są trzy najważniejsze czynniki zniechęcające do sięgania po starożytne homilie. Pierwszym jest rozmiar korpusu homilii, który już w punkcie wyjścia zniechęca badaczy. Przykładowo, w katalogu dzieł Jana Chryzostoma znajduje się ok. tysiąca homiliii ${ }^{21}$, które zachowały się do

${ }^{20}$ Por. M.B. Cunningham, Preaching and the Community, w: Church and People in Byzantium, Society for the Promotion of Byzantine Studies Twentieth Spring Symposium of Byzantine Studies, Manchester 1986, ed. R. Morris, Birmingham 1990, 29-46; A. Olivar, La predicación christiana antigua, Biblioteca Herder, Sección de teología y filosofía 189, Barcelona 1991; P. Allen - W. Mayer, Computer and Homily: Accessing the Everyday Life of Early Christians, VigCh, 47 (1993) 260280; J.C. Salzmann, Lehren und Ermahnen. Zur Geschichte des christlichen Wortgottesdienstes in den ersten drei Jahrhunderten, Wissenschaftliche Untersuchungen zum Neuen Testament, 2. Reihe, 59, Tübingen 1994. Teologicznie ukierunkowany przegląd starożytnych kazań znajduje się w: A. Hamman, Dogmatik und Verkündigung in der Väterzeit, „Theologie und Glaube” 61 (1971) 109140 (kazania Ojców Wschodnich); tenże, Dogmatik und Verkündigung in der Väterzeit, „Theologie und Glaube" 61 (1971) 202-231 (kazania Ojców Zachodnich). Aby zapoznać się z problematyką kazań koptyjskich zob. C.D.G. Müller, Einige Bemerkungen zur «ars praedicandi» der alten koptischen Kirche, „Muséon” 67 (1954) 231-270. Należy też wymienić dwie prace oferujące wgląd w studia nad przepowiadaniem w czasach Ojców Kościoła: De ore Domini. Preacher and the Word in the Middle Ages, ed. T.L. Amos - E.A. Green - B. Mayne Kienzle, Studies in Medieval Culture 27, Kalamazoo 1989; De l'homélie au sermon. Histoire de la prédication médiévale, éd. J. Hamesse - X. Hermand, Publications de l'Institut d'Études Médiévales. Textes, Études, Congrès 14, Louvain-la-Neuve 1993.

${ }^{21}$ Przeprowadzone przeze mnie obliczenia wskazuja, że z homilii wygłoszonych przez Jana Chryzostoma w Antiochii zachowało się aż 636; por. Szczur, Problematyka społeczna w późnoantycznej Antiochii, s. 33. 
naszych czasów albo w całości, albo przynajmniej w części ${ }^{22}$. Drugim są częste problemy z autentycznością lub atrybucją poszczególnych homilii, spowodowane głównie tym, że duża ich liczba została przekazana pod imionami słynnych kaznodziejów, takich jak np. Jan Chryzostom, ale w rzeczywistości nie należy do spuścizny tych autorów. Trzecim jest brak wydań krytycznych homilii, co utrudnia lub wręcz uniemożliwia systematyczną analizę ich zawartości (zwłaszcza teologicznej czy filozoficznej). Ilość zachowanych manuskryptów, w szczególności niektórych serii homiletycznych, jest ogromna, a czas potrzebny na zbadanie wszystkich grup rękopisów, zważywszy na znaczną ich ilość oraz - niekiedy - objętość homilii, jest bardzo długi. Doprowadziło to do dwóch zauważalnych zjawisk: bardzo wolnej publikacji edycji krytycznych oraz powstania wśród wydawców tendencji do zajmowania się w pierwszej kolejności krótkimi homiliami i niewielkimi seriami homiletycznymi.

Chociaż uczeni wysuwają wiele zastrzeżeń związanych z traktowaniem starożytnych homilii jako źródeł historycznych, to jednak w ostatnim czasie daje się zauważyć wzmożone ich wykorzystywanie, zwłaszcza w badaniach historii społecznej ${ }^{23}$, czy dziejów liturgii ${ }^{24}$. W tym kontekście należy zauważyć, że ważne jest, by w prowadzonych badaniach nie przyjmować bezkrytycznie informacji na temat codziennego życia zawartych w homiliach. S.R. Holman ${ }^{25}$ zwraca uwagę, aby korzystając ze starożytnych homilii jako źródeł, uwzględniać retorykę i moralizatorstwo autorów, i oddzielać je od warstwy historycznej. Należy też konfrontować informacje zawarte w homiliach z danymi dostępnymi już z innych źródeł (np. tekstów świeckich z tego okresu) i innych dyscyplin wiedzy (np. archeologii, papirologii czy epigrafiki).

2. Ekonomiczny wymiar głodu i niedoboru żywności. Zaspokojenie głodu jest jedną z podstawowych potrzeb człowieka, dlatego ludzie w starożytnych społecznościach bali się głodu i wynikającego z niego cierpienia ${ }^{26}$.

${ }^{22}$ Por. Clavis Patrum Graecorum, vol. 2: Ab Athanasio ad Chrysostomus, cura et studio M. Geerard, Turnhout 1974, 491-672.

${ }^{23}$ Można tu wspomnieć następujące prace: H. Berthold, Frühe christliche Literatur als Quelle fur Sozialgeschichte, w: Das Korpus der Griechischen Christlichen Schriftsteller: Historie, Gegenwart, Zukunft, hrsg. von J. Irmscher - K. Treu, TU 120, Berlin 1977, 43-63; R.L. Wilken, John Chrysostom and the Jews. Rhetoric and Reality in the Late Fourth Century, Berkeley - Los Angeles - London 1983; J.C.B. Petropoulos, The Church Father as Social Informant St John Chrysostom on folk-songs, StPatr 23 (1989) 159-164; R. MacMullen, The preacher's audience (AD 350-400), JTS 40 (1989) 503-511; Szczur, Problematyka społeczna (tam też dalsza literatura).

${ }^{24}$ Można tu wspomnieć następujące prace: F. van de Paverd, Zur Geschichte der Messliturgie in Antiocheia und Konstantinopel gegen Ende des vierten Jahrhunderts, OCA 187, Rome 1970; R. Kaczynski, Das Wort Gottes in Liturgie und Alltag der Gemeinden des Johannes Chrysostomus, Freiburger Theologische Studien 94, Freiburg - Basel - Wien 1974; J.F. Baldovin, The Urban Character of Christian Worship The Origins, Development and Meaning of Stational Liturgy, OCA 228, Rome 1987.

${ }^{25}$ Por. Holman, The Hungry are Dying, s. 443.

${ }^{26}$ Por. Joannes Chrysostomus, Ad populum Antiochenum hom. 5, 3, PG 49, 72, thum. Iluk, s. 70: 
Z tego też względu, w sytuacji zagrożenia głodem, podejmowali się wykonywania nawet takich prac, których normalnie by nie wykonywali. Jan Chryzostom mówi, że rolnik, gdyby musiał zająć się ziemią trudną do uprawy, w normalnych warunkach zrezygnowałby z niej, jednak z obawy przed głodem będzie ją uprawiał ${ }^{27}$.

Wspólne życie i związany z nim równomierny podział żywności, pomagały w złagodzeniu trudności ekonomicznych i dostarczeniu żywności głodnym. Przykładowo, jednym z celów klasztorów - jak mówi Chryzostom - była ochrona ludzi przed głodem ${ }^{28}$. Złotousty w głoszonej homilii nie mógł wymienić ani jednego przypadku, kiedy mnich umarłby z głodu. W tym kontekście, odnosząc się do zwykłej rodziny składającej się z dziesięciorga dzieci oraz ich rodziców, wyjaśnia on podstawową zasadę ekonomiczną. Mówi, że tańsze jest utrzymanie rodziny, gdy wszyscy mieszkają razem i jedzą przy jednym stole, niż gdyby każdy z jej członków żył i żywił się osobno. Dlatego też klasztory nie tylko ułatwiały mnichom przetrwanie okresów głodu, lecz także pomagały ludziom głodujący, a z biegiem czasu pochodząca z klasztorów pomoc, coraz bardziej wzrastała ${ }^{29}$.

Chryzostom mówi, że za głód ubogich odpowiedzialni są ludzie boga$\mathrm{ci}^{30}$. Stwierdzenie to opiera się nie tylko na założeniu ekonomicznym (że dostępność towarów jest ograniczona) lub na odniesieniu się do kategorii społecznych (że bogaci powinni udzielać jałmużny ubogim). Do swych argumentów Chryzostom dołącza jeszcze pewną koncepcję, mówiącą o tym, że ludzie zamożni niewłaściwie wykorzystują posiadane przez siebie dobra ${ }^{31}$ z powodu niewłaściwej oceny ich wartości ${ }^{32}$. Uważają, że złoto jest cenniejsze niż żelazo, pomimo że żelazo jest bardziej przydatne, ponieważ jest wykorzystywane do wielu rzeczy i dzięki niemu może być zaspokojonych wiele ludzkich potrzeb. Podobnie bogaci nie zdają sobie sprawy z tego, że kamienie używane do budowy domów są bardziej przydatne niż kamienie

\footnotetext{
„A czy od głodu większe są męczarnie?”. Zob. J. Strojnowski, Głód, I. Aspekt biologiczno-medyczny, EK V 1144: „Głód jest poczuciem ogólnym o różnym nasileniu i jakości, od umiarkowanego i pozytywnego (apetytu i łaknienia) aż do bolesnego cierpienia wywołanego brakiem lub niedoborem pożywienia".

${ }^{27}$ Por. Joannes Chrysostomus, De sacerdotio V 8, éd. A.-M. Malingrey, SCh 272, Paris 1980, 300, tłum. W. Kania: Św. Jan Chryzostom, Dialog «O kapłaństwie», BOK 1, Kraków 1992, 126: „Podobnie tu jest jak z rolnikiem, uprawiającym jałową rolę i orzącym kamienny grunt. Zaprzestanie on wnet pracy, jeśli go nie ogarnie zapał do wysiłków lub nie zmusi obawa przed głodem".

${ }^{28}$ Por. tenże, In Acta Apostolorum hom. 11, 3, PG 60, 97.

${ }^{29}$ Por. Finn, Almsgiving in the Later Roman Empire, s. 114.

${ }^{30}$ Por. Joannes Chrysostomus, Ad illuminandos cat. 2, 4(15), PG 49, 237, thum. W. Kania, w: Św. Jan Chryzostom, Katechezy chrzcielne (homilie katechetyczne do tych, którzy maja otrzymać chrzest [zostać oświeceni] oraz do neofitów 9-12), oprac. M. Starowieyski, U Źródeł Katechumenatu 2, Lublin 1994, 62: „Abyś mógł się ozdobić jedna perłą, tysiące ubogich muszą głodować”.

${ }^{31}$ Por. Szczur, Problematyka społeczna w późnoantycznej Antiochii, s. 157-172.

${ }^{32}$ Por. tamże, s. 130-132.
} 
szlachetne. Z powodu błędnego myślenia koncentrują się na zdobywaniu i gromadzeniu bogactwa, a zupełnie zapominają o tym, że powinno ono służyć zaspokajaniu ludzkich potrzeb ${ }^{33}$.

W społeczeństwie antycznym istniała głęboka przepaść między ludźmi bogatymi i biednymi. Rzeczywistością ekonomiczną był fakt, że chociaż byli ludzie, których nie stać było na zakup chleba, to również byli i tacy, którzy marnowali go, pomimo głodowania przez innych ${ }^{34}$. Chryzostom często podkreśla tę nierówność ekonomiczną, porównując los osoby głodnej z życiem człowieka bogatego ${ }^{35}$. Z jednej strony mówi o wielkim zbytku ludzi zamożnych przywiązanych do luksusu ${ }^{36}$, którzy w swych domach posiadali wiele sprzętów codziennego użytku wykonanych ze szlachetnych kruszców - srebra lub złota oraz kości słoniowej i jedwabiu, a nawet przyozdabiali złotem głowy mułów, które były zaprzęgane do kosztownych wozów służących do wożenia żon bogaczy. Z drugiej zaś strony mówi o ludziach ubogich, członkach wspólnoty Kościoła - Ciała Chrystusa, którzy nie mają nawet wystarczającej ilości pożywienia ${ }^{37}$.

Ludzie zamożni często wykorzystywali też niedobór żywności i głód, aby się wzbogacić. Najczęściej dochodziło do spekulacji cenami żywności w związku z sezonowymi lub lokalnymi trudnościami z zaopatrzeniem w nią, zwłaszcza w zboże. Nieurodzaj i spowodowany nim głód, był bardzo dobrą okazją dla spekulantów do podwyższania cen żywności. Bogaci handlarze rozpoczynali sprzedaż zboża dopiero wtedy, gdy jego cena była wysoka i gwarantowała im największy zysk. W takich sytuacjach Jan Chryzostom apelował do właścicieli spichlerzy, aby nie czekali na głód, by osiagnąć jak największy $z y^{38}{ }^{38}$. Antiocheńczyk mówi też o suszy, która kiedyś nawiedziła jego miasto $^{39}$. Ludzie modlili się o deszcz, który Bóg im w końcu zesłał. Gdy spadł obfity deszcz wszyscy byli uradowani z wyjątkiem jednego bogatego człowie-

\footnotetext{
${ }^{33}$ Por. tamże, s. 172-176.

${ }^{34}$ Por. Millman - Kates, Toward Understanding Hunger, s. 12.

${ }^{35}$ Por. B. Leyerle, John Chrysostom on Almsgiving and the Use of Money, HTR 87 (1994) 29.

${ }^{36}$ Por. Szczur, Problematyka społeczna w późnoantycznej Antiochii, s. 127-128.

${ }^{37}$ Por. Joannes Chrysostomus, In epistulam ad Romanos hom. 11, 6, PG 60, 492, thum. W. Sinko:
} Św. Jan Chryzostom, Homilie na list św. Pawła do Rzymian, oprac. A. Baron, t. 1, Kraków 1995, 171-172: „Ten, który został stworzony na obraz Boga (por. Rdz 1, 27), stoi w haniebnych łachmanach z powodu twej nieludzkości, a głowy mułów, wiozących twoją żonę, błyszczą od mnogiego złota, a także skóry i drewna, tworzące nad nią zasłonę. I czy potrzeba sporządzić tron czy podnóżek, wszystko sporządza się ze złota i srebra: a współuczestnik ciała Chrystusa, dla którego On z nieba zstąpił i przelał cenną krew, nie spożywa nawet nieodzownego pokarmu z powodu twojej chciwości. Sofy są u ciebie ze wszystkich stron ozdobione srebrem, a ciała świętych nie mają nawet koniecznego przykrycia. Chrystus w mniejszej jest u ciebie cenie, niż wszystko inne, niż służba, muły, tron czy podnóżek". Sytuację zamożnych ludzi w Antiochii w IV w. szerzej opisuje J.H.W.G. Liebeschuetz, The Finances of Antioch in the Fourth Century A. D., ByZ (1959) 344-356.

${ }^{38}$ Por. Joannes Chrysostomus, In Joannem, hom. 60, 6, PG 59, 334-335.

${ }^{39}$ Por. tenże, In epistulam I ad Corinthios hom. 39, 7, PG 61, 343. 
ka, który wyznał, że ma dziesięć tysięcy miar pszenicy ${ }^{40}$, i że już nie będzie mógł ich sprzedać z wielkim zyskiem. Chryzostom podkreśla, że podczas gdy głodni ludzie radowali się z powodu deszczu, bogacz ów cierpiał ${ }^{41}$.

Złotousty kaznodzieja zauważa, że ludziom często trudno jest uciec od życia w ubóstwie, a z jego powodu wielu cierpi głód przez całe życie ${ }^{42}$, mimo że pracują oni nawet przez całą zimę, narażeni na mróz i deszcz. Dzieje się tak z powodu chciwości ich patronów, którzy ich wyzyskują ${ }^{43}$. Z wypowiedzi Antiocheńczyka wynika, że z głodem nieustannie zmagali się w głównej mierze ludzie pracujący na $\mathrm{wsi}^{44}$.

Wobec znacznej liczby ludzi cierpiących z powodu niedoboru żywności Chryzostom przedstawia interesujący program zlikwidowania głodu w Antiochii. Chce, by ludzie zamożni i żyjący dostatnio podzielili między siebie głodujących nędzarzy i zadbali o dostarczanie im chleba i odzieży. Wówczas jak wskazuje Chryzostoma - ,na pięćdziesięciu, a może nawet na stu” obywateli zamożnych lub żyjących dostatnio, przypadłby zaledwie jeden głodujący:

„przyjrzyjmy się, jeśli chcecie, kogo jest w mieście więcej, ubogich, bogatych czy tych, którzy nie są ani ubodzy, ani bogaci, lecz znajdują się pośrodku. Ubodzy stanowią dziesiątą część, bogaci dziesiątą, reszta znajduje się pośrodku. Podzielmy całą liczbę ludności miasta przez liczbę ubogich, a zobaczycie, jak wielki wstyd dla was. Mało jest ludzi bardzo bogatych, ale wielu takich, którzy idą po nich; ubogich natomiast o wiele mniej aniżeli tych. A jednak wielu z nich kładzie się spać z pustym żołądkiem, choć tak wielu jest ludzi, którzy mogliby nakarmić głodnych nie dlatego, żeby ci, którzy mają, nie mogli z łatwością dostarczyć im tego, co potrzeba, lecz dlatego, że są okrutni i nieludzcy. Gdyby bogaci i ci, którzy mają średni majątek, podzielili między siebie tych, którzy potrzebują chleba i odzieży, to zaledwie jeden ubogi wypa-

${ }^{40} \mathrm{~W}$ podanej przez Chryzostoma ilości zboża zgromadzonego przez bogacza: „dziesięć tysięcy miar", widoczna jest przesada retoryczna, której celem było wskazanie na wielkość zgromadzonych zapasów, bez określania konkretnej ilości zboża.

${ }^{41}$ Por. Joannes Chrysostomus, In epistulam I ad Corinthios hom. 39, 7, PG 61, 343. Na temat spekulacji cenami zboża w czasie głodu zob. D. Rathbone, The Grain Trade and Grain Shortages in the Hellenistic East, w: Trade and Famine in Classical Antiquity, s. 49.

${ }^{42}$ Por. Joannes Chrysostomus, In paralyticum demissum per tectum 8, PG 51, 61; tenże, Ad populum Antiochenum hom. 1, 10, PG 49, 30.

${ }^{43}$ Por. tenże, In Matthaeum hom. 61, 3, PG 58, 591, tłum. J. Krystyniacki: Św. Jan Chryzostom, Homilie na Ewangelię wedtug św. Mateusza, oprac. A. Baron, t. 2, ŹMT 23, Kraków 2001, 238: „Na przymierających głodem i pracujących przez całe życie nakładają bez ustanku nieznośne daniny, nakazują im ciężkie służby, posługują się ich ciałami jak osłami i mułami, a raczej jak kamieniami, nie pozwalając im ani na chwilę spoczynku. Czy ziemia rodzi czy nie, męczą ich w jednakowy sposób i nie mają nad nimi żadnej litości. Cóż może być boleśniejszego niż to, że pracując przez całą zimę, marnując swe siły na zimnie, w deszczu i bezsenności, odchodzą z próżnymi rękami i jeszcze pozostają dłużni? Że bardziej się boją znęcania się nadzorców, ich zdzierstw, grabieży, więzienia, nieuniknionych służb, niż tego głodu i grzęźnięcia”.

${ }^{44}$ Por. tenże, In epistulam ad Colossenses hom. 1, 5, PG 62, 306. 
dałby na pięćdziesięciu a może nawet na stu. A jednak żyją oni w nędzy, mimo tak wielkiej liczby tych, którzy mogą dostarczyć potrzebnych rzeczy"45.

Chociaż przedstawiony program wydaje się być atrakcyjny, to już na pierwszy rzut oka widać, że Chryzostom gubi się w prezentowanych wyliczeniach. Najpierw mówi, że ,ubodzy stanowią dziesiątą część, bogaci dziesiąta, reszta znajduje się pośrodku”. Zatem 10\% mieszkańców Antiochii stanowili ubodzy, a 90\% ludzie żyjący dostatnio lub nawet zamożni. Z tego wynika, że jeden ubogi przypadałby na 9 ludzi nie cierpiących głodu, a nie ,na pięćdziesięciu a może nawet na stu" - jak nieco dalej twierdzi Chryzostom. Jednak i te wskazania Chryzostoma mogą budzić watpliwości, gdyż - jak zauważa Wendy Mayer ${ }^{46}$ i Peter Brown ${ }^{47}$, Chryzostom w powyższej wypowiedzi najprawdopodobniej minimalizuje poziom ubóstwa i równocześnie wyolbrzymia poziom bogactwa, aby pokazać, jak łatwo bogaci mogą rozwiązać problem ubóstwa i głodu.

3. Społeczny wymiar głodu i niedoboru żywności. W pismach Chryzostoma odnajdujemy żywy opis skutków społecznych głodu w środowiskach, w których działał. Z jego przekazów wynika, że liczba ludzi głodujących była znaczna. Wojny, klęski żywiołowe, wyzysk latyfundystów i powodowana nimi bieda, a w konsekwencji głód, zmuszały wielu do szukania szczęścia w mieście. Głodni żebracy, oczekując na pomoc, ustawiali się wzdłuż ulic, na rynku $^{48}$, przed łaźniami i przed drzwiami kościołów ${ }^{49}$. Złotousty Kaznodzieja zaświadcza, że potrzeby w tym względzie rosły zimą, gdy zwiększała się liczba bezrobotnych ${ }^{50}$.

Antiocheńczyk mówi, że ludzie biedni udają się głodni ${ }^{51}$ na spoczynek, a doświadczający niedoboru żywności żebracy są wycieńczeni z powodu gło$\mathrm{du}^{52}$, co też niekiedy prowadziło do śmierci ${ }^{53}$. Głodni ludzie lamentując chodzą po ulicach i rynku, a chwiejąc się wyciągają ręce do przechodniów i proszą ich

${ }^{45}$ Tenże, In Matthaeum hom. 66, 3, PG PG 58, 630, ŹMT 23, 296.

${ }^{46}$ Por. W. Mayer, Poverty and Society in the World of John Chrysostom, w: Social and Political Archaeology in Late Antiquity, ed. L. Lavan - W. Bowden - A. Gutteridge - C. Machado, Late Antique Archaeology 3, Leiden 2006, 468.

${ }^{47}$ Por. P. Brown, Poverty and Leadership in the Later Roman Empire, Hanover - London 2002, 14.

${ }^{48}$ Por. Joannes Chrysostomus, In Genesim ser. 5, 4, éd. L. Brottier, SCh 433, Paris 1998, 272.

${ }^{49}$ Por. tenże, In epistulam I ad Corinthios hm. 30, 4, PG 61, 254; tenże, In Genesim, ser. 5, 3, SCh 433, 270 - gdzie Antiocheńczyk mówi o szeregu biedaków stojących przed kościołem, obok których obojętnie przechodzili wierni wychodzący z nabożeństwa.

${ }^{50}$ Por. tenże, De eleemosyna 1, PG 51, 261; tenże, In epistulam I ad Corinthios, hom. 21, 5, PG 61, 177; 30, 4, PG 61, 255; tenże, In epistulam II ad Corinthios, hom. 7, 6, PG 61, 451.

${ }^{51}$ Por. tenże, In Matthaeum hom. 66, 3, PG 58, 630, ŹMT 23, 296: „A jednak wielu z nich [tj. ludzi ubogich] kładzie się spać z pustym żołądkiem, choć tak wielu jest ludzi, którzy mogliby nakarmić głodnych".

${ }^{52}$ Por. tenże, In Eutropium 2, PG 52, 393.

${ }^{53}$ Por. tenże, Ad Theodorum lapsum I 7, ed. J. Dumortier, SCh 117, Paris 1966, 114. 
o chleb $^{54}$. Wałęsają się w zaułkach jak bezdomne psy i śpią na wiązce słomy ${ }^{55}$. Natomiast ludzie bogaci w tym samym czasie siedzą w swoich domach przy suto zastawionych stołach, śmieją się i bawią, i nie zwracają uwagi na głosy ludzi głodnych ${ }^{56}$.

Z wypowiedzi Chryzostoma wynika, że niektórych ludzi głód doprowadzał do takiego stanu, iż byli w gotowi zrobić wszystko, co w ich mocy, aby innych skłonić do litości. Nawet oślepiali swe dzieci, aby w ten sposób wzbudzić w innych współczucie ${ }^{57}$. Ludzie ci myśleli, że lepiej nie oglądać słońca, niż ciagle walczyć z głodem. Złotousty podaje więcej przykładów tego, co byli w stanie zrobić głodni, gdy ich słowa i gesty pozostawały bez odzewu ${ }^{58}$ : jedli skóry ze zniszczonych butów, wbijali sobie paznokcie w głowy i zanurzali się w lodowatej wodzie, aby tylko przyciągnąc uwagę innych ludzi i wzbudzić w nich litość. Chryzostom jest przekonany, że ci biedni i głodni ludzie swymi wyczynami przewyższają cudotwórców. Innych głód zmuszał do pracy w roli kuglarzy, błaznów i „oratorów” wygłaszających plugawe mowy oraz dawania pokazów muzycznych. Owi muzykanci, posługując się kubkami i miskami jako cymbałami oraz fletami i gwizdkami, śpiewali sprośne piosenki, aby w ten sposób dostarczyć rozrywki widowni ${ }^{59}$. Widzowie zgromadzeni wokół nich śmiali się i - jak mówi Chryzostom - „gloryfikowali nieszczęścia innych". Antiocheńczyk zauważa, że tym poniżającym się ludziom bogacze dawali niekiedy obola lub kawałek chleba i zachęcali ich do bardziej ekstremalnych ,pokazów”. Jednak, gdy głodni spokojnie, z modlitwą na ustach, zbliżali się do ludzi bogatych prosząc ich o wsparcie, ci po prostu ignorowali ich, a niekiedy rzucali pod ich adresem złośliwe komentarze, takie jak: „Czy ten [człowiek] musi żyć? czy musi w ogóle oddychać? oglądać to słońce?"60

Głód i lęk przed głodem mogą niejako zmusić człowieka do wyzbycia się wstydu. Jan Chryzostom mówi o wdowach, które z racji ubóstwa żebrały i prosiły o pomoc, pomimo tego, iż były obrażane ${ }^{61}$. Wspomina też, że głód

\footnotetext{
${ }^{54}$ Por. tenże, In Joannem hom. 77, 4, PG 59, 418.

${ }^{55}$ Por. tenże, In epistulam I ad Corinthios hom. 11, 5, PG 61, 94.

${ }^{56}$ Por. tenże, In Genesim ser. 5, 4, SCh 433, 272-274, tłum. S. Kaczmarek, ŹMT 45, Kraków 2008, 89: „gdy zatem przygotowano stół, a słyszymy, jak oni [tj. głodni żebracy] na dole chodzą po wąskich uliczkach i głośno krzyczą pomiędzy domami, jak znoszą cierpienie w najgęstszym mroku, w wielkim osamotnieniu, nawet wówczas się nie pochylamy. Nawet gdy nasyceni udajemy się powoli do snu i znów w tym czasie słyszymy, jak oni na dole głośno lamentują, przechodzimy obojętnie, jakbyśmy słyszeli głos wściekłego psa, a nie głos ludzki”; tenże, In Joannem hom. 77, 4,

${ }^{57}$ Por. tenże, In epistulam I ad Corinthios hom, 21, 5, PG 61, 177.

${ }^{58}$ Por. tamże 21, 5-6, PG 61, 177.

${ }^{59}$ Por. tenże, In epistulam I ad Thessalonicenses hom. 11, 3, PG 62, 465.

${ }^{60}$ Tenże, In epistulam I ad Corinthios hom, 21, 6, PG 61, 177, thum. własne.

${ }^{61}$ Por. tenże, De sacerdotio III 12, SCh 272, 206, BOK 1, 91: „Choćby je nawet głód zmusił do
} PG 59, 418. 
niekiedy skłaniał kobiety także do prostytucji ${ }^{62}$. Mówiąc o tym Chryzostom jednak twierdzi, że nie jest to - oczywiście - wystarczające usprawiedliwienie dla kobiet oddających swe ciało za pieniądze ${ }^{63}$, ponieważ mogłyby zarobić na chleb dzięki godziwej pracy. Jak widać - w przekonaniu Antiocheńczyka prostytutki miały alternatywę, aby zaradzić głodowi, jednak istniały też takie grupy ludzi, którzy nie mieli możliwości jakiegokolwiek wyboru. Taką grupą byli np. więźniowie. Powszechną praktyką było złe ich traktowanie i potęgowanie ich cierpień poprzez brak żywności. Chryzostom mówi, że gdyby ktoś wszedł do więzienia, to zobaczyłby więźniów zakutych w kajdany, którzy byli brudni, zarośnięci i ubrani w łachmany. Inni byli okaleczeni, z widocznymi na ciele ranami, a umierający z głodu łasili się jak psy do nóg tych, którzy przybywali do więzienia. Strażnicy więzienni prowadzili więźniów w łańcuchach na rynek, gdzie przez cały dzień musieli błagać o jałmużnę, a gdy nadchodził wieczór, ich opiekunowie zabierali znaczną część zebranych pieniędzy, nie zostawiając im środków nawet na niezbędne pożywienie ${ }^{64}$.

W tym miejscu należy zauważyć, że na tak drastyczne sceny i opisy życia żebraków trzeba patrzeć z wielką ostrożnością i krytycznie je oceniać, gdyż istnieje wielkie prawdopodobieństwo, że Chryzostom - opisując trudną sytuację ludzi cierpiących z powodu głodu - wyolbrzymiał ich nieszczęścia. Można przypuszczać, że opisy te były pewnego rodzaju zabiegiem retorycznym mającym na celu wywołanie emocji i przekonanie słuchaczy do udzielania wsparcia ludziom cierpiącym głód ${ }^{65}$. Na taką ewentualność zwracają też uwagę Holman ${ }^{66}$ i Mayer ${ }^{67}$. Należy jednak podkreślić, że opisy te, aby przyniosły oczekiwane efekty, nie mogły być całkowicie oderwane od rzeczywistości i musiały, w mniejszym lub większym stopniu, odnosić się do codziennych doświadczeń słuchaczy.

Głód może też wpływać na wzrost przestępczości ${ }^{68}$. W tym kontekście interesujące jest stanowisko Chryzostoma w kwestii kradzieży dokonywanych przez ludzi głodnych. Otóż przywołując wypowiedź z Księgi Przysłów (6, 30.32): „Nie ma hańby dla tego, który kradnie, by wnętrze napełnić, gdy głodny [...], ale kto cudzołoży, ten wiedzie na zgubę duszę swoją", kaznodzieja porównuje kradzież z cudzołóstwem i stwierdza, że

\footnotetext{
pokonania wstydu, to przecież nie stają się przez to mniej wrażliwe na zniewagi. Zmuszone żebrać jeszcze bardziej cierpią i zewsząd ogarnia ich duszę jakaś ciemna noc zwątpienia”.

${ }^{62}$ Por. Mayer, Poverty and Society in the World of John Chrysostom, s. 471.

${ }^{63}$ Por. Joannes Chrysostomus, In epistulam ad Hebraeos hom. 15, 3, PG 63, 120.

${ }^{64}$ Por. tenże, In Joannem hom. 60, 4, PG 59, 333.

${ }^{65}$ Por. P. Allen - B. Neil - W. Mayer, Reading the Texts: A Methodology of Approach to Genre, w: Preaching Poverty in Late Antiquity, s. 36-68.

${ }^{66}$ Por. S.R. Holman, Constructed and Consumed: The Everyday Life of the Poor in $4^{\text {th }} C$. Cappadocia, w: Social and Political Life in Late Antiquity, s. 447.

${ }^{67}$ Por. Mayer, Poverty and Society in the World of John Chrysostom, s. 466.

${ }^{68}$ Por. Strzeszewski, Głód, II. Aspekt społeczno-ekonomiczny, s. 1144.
} 
„ciężko grzeszy złodziej, ale nie tak ciężko, jak cudzołożnik. Pierwszy może na swoją obronę przywołać choćby bezpodstawną przyczynę - ubóstwo; drugi, niczym nie przymuszany, z samej głupoty wpada w otchłań nieprawości”“99.

Z przytoczonej wypowiedzi jednoznacznie wynika, że choć kradzież Jan Chryzostom uważa za poważny grzech, to jednak ubóstwo, skłaniające ludzi głodnych do kradzieży, stanowi pewnego rodzaju usprawiedliwienie moralnie złego czynu.

Lektura homilii Jan Chryzostoma skłania do wniosku, że nagminne było kierowanie pod adresem żebraków niegrzecznych uwag. Przykładowo, osobę, która prosiła o chleb lub jednego obola na zakup chleba, często nazywano „zwodzicielem” lub „oszustem”70. Chryzostom twierdzi, że gdyby jakaś osoba prosiła o złoto, srebro lub kosztowne ubrania, to słusznie można by ją nazwać „oszustem”, ale nie można tego uczynić, gdy prosi tylko o jedzenie. Wspomniane sytuacje wiele mówią na temat różnic społecznych, ukazując jak niektórzy - dla pokazania wyższej pozycji społecznej - potrafią poniżać innych, znajdujących się w trudnej sytuacji życiowej.

Chryzostom mówi, że od ludzi, którzy błagali o chleb oczekiwano, aby chwalili tych, którzy ulitowali się nad nimi ${ }^{71}$. Odbiorcy jałmużny okazywali zatem wdzięczność dobroczyńcom szanując ${ }^{72}$ ich i publicznie chwaląc ${ }^{73}$. Sytuacje tego typu, opisywane przez kaznodzieję, są bardzo dobrymi przykładami systemu patronatu, w którym patroni (dobroczyńcy) wyświadczali jakieś dobrodziejstwa klientom, a zobowiązani do wdzięczności klienci (odbiorcy) odpowiadali wychwalając swych patronów.

\section{$* * *$}

Z przedstawionych analiz wynika, że głód i niedobór żywności były zjawiskami dość powszechnymi w starożytnym społeczeństwie i wpisanymi w pejzaż codziennego życia. Nie dziwi więc fakt, że Jan Chryzostom zachęcał wiernych do wrażliwości na sytuację ludzi dotkniętych głodem i zaradzania ich potrzebom. Kaznodzieja opisując życie ludzi ubogich, a szczególnie cierpiących z powodu głodu, ukazywał ich jako mających moralne prawo do otrzymywania pomocy. Należy jednak pamiętać, że opisy ludzkiej nędzy zawarte na kartach homilii i kazań Jana Chryzostoma, dość często były przejaskrawiane i dostosowywane do konkretnych sytuacji. Z tego względu nale-

${ }^{69}$ Joannes Chrysostomus, Ad populum Antiochenum hom. 10, 6, PG 49, 118, thum. Iluk, s. 127.

${ }^{70}$ Por. tenże, In epistulam ad Romanos hom. 14, 9, PG 60, 535, thum. Sinko, s. 232: „Gdy ktoś zbliży się do nas prosząc o jeden grosz, obrażamy go, łajamy, nazywamy oszustem. Czy nie drżysz człowieku, nie rumienisz się, nazywając kogoś oszustem dlatego, że żebrze chleba?"; tenże, In Joannem hom. 77, 4, PG 59, 418; tenże, In epistulam ad Hebraeos hom. 11, 4, PG 63, 96.

${ }^{71}$ Por. tenże, In epistulam I ad Thessalonicenses hom. 11, 3, PG 62, 465.

${ }^{72}$ Por. Holman, The Hungry are Dying, s. 32.

${ }^{73}$ Por. Joannes Chrysostomus, In epistulam II ad Corinthios hom. 2, 4, PG 61, 398. 
ży analizować je z wielką wnikliwością i ostrożnością. Niemniej, informacje przekazane przez Chryzostoma na temat głodu są bardzo istotne i przydatne w odkrywaniu realiów stosunków społecznych czasów, w których żył.

Na podstawie nauczania homiletycznego złotoustego kaznodziei można wyciagnąć wniosek, że wzywanie do pomocy biednym, zwłaszcza głodnym było przewodnim motywem jego kazań. Można nawet powiedzieć, że w jego kazaniach jak refren piosenki powracało stwierdzenie, że głodni znajdują się w potrzebie i konieczna jest im pomoc ze strony ludzi, którzy nie borykają się z problemem głodu.

\section{HUNGER AS AN ECONOMIC AND SOCIAL PROBLEM IN JOHN CHRYSOSTOM'S HOMILETIC TEACHING}

\section{(Summary)}

The article consists of three parts covering consecutively the question of treating ancient homilies as historic sources, the economic dimension of hunger and food shortages, and finally, their social dimension. The analyses presented show that hunger and food shortages were quite common phenomena in ancient societies and they were intrinsically woven into the fabric of their everyday lives. In his homilies John Chrysostom encouraged his congregation not only to show their social conscience in the face of starving people, but also to help those in need. Describing lives of the poor, especially those suffering from hunger, the preacher pictured them as morally entitled to receiving help. We should though remember that descriptions of destitution in John Chrysostom's homilies and sermons were quite often exaggerated and designed to serve preacher's specific purpose. This is the reason why we should approach their analyses with extreme caution and thoroughness. Nevertheless, the information on the issue of hunger given by Chrysostom is still valuable and useful in discovering the reality of social relationships in his time.

Key words: John Chrysostom, hunger, destitution, ancient homilies, economic issues, social issues.

Słowa kluczowe: Jan Chryzostom, głód, starożytne homilie, problematyka ekonomiczna, problematyka społeczna.

\section{BIBLIOGRAFIA}

\section{Źródła}

Joannes Chrysostomus, Ad illuminandos cat. 2, PG 49, 231-240, thum. W. Kania, w: Św. Jan Chryzostom, Katechezy chrzcielne (homilie katechetyczne do tych, którzy maja otrzymać chrzest [zostać oświeceni] oraz do neofitów 9-12), oprac. M. Starowieyski, U źródeł katechumenatu 2, Lublin 1994, 51-68 [Katecheza 12]. 
Joannes Chrysostomus, Ad populum Antiochenum hom. 1-21, PG 49, 15-222, thum. J. Iluk:

Św. Jan Chryzostom, Mowy do Antiocheńczyków o posagach, Gdańsk 2017.

JoAnnes Chrysostomus, Ad Theodorum lapsum, ed. J. Dumortier, SCh 117, Paris 1966.

Joannes Chrysostomus, De eleemosyna, PG 51, 261-272.

Joannes Chrysostomus, De sacerdotio, ed. A.-M. Malingrey, SCh 272, Paris 1980, thum.

W. Kania: Św. Jan Chryzostom, Dialog «O kaptaństwie», BOK 1, Kraków 1992.

JoAnnes Chrysostomus, In Acta Apostolorum hom. 1-55, PG 60, 13-384.

JoAnnes Chrysostomus, In epistulam ad Colossenses hom. 1-12, PG 62, 299-392.

JoAnnes Chrysostomus, In epistulam ad Hebraeos hom. 1-34, PG 63, 9-236.

JoAnnes Chrysostomus, In epistulam ad Romanos hom. 1-32, PG 60, 391-682, thum. W. Sin-

ko: Św. Jan Chryzostom, Homilie na list św. Pawła do Rzymian, oprac. A. Baron, t. 1-2,

Kraków 1995-1998.

Joannes Chrysostomus, In epistulam I ad Corinthios hom. 1-44, PG 61, 9-382.

Joannes Chrysostomus, In epistulam I ad Thessalonicenses hom. 1-11, PG 62, 391-468.

Joannes Chrysostomus, In epistulam II ad Corinthios hom. 1-30, PG 61, 381-610.

JoAnnes Chrysostomus, In Eutropium, PG 52, 391-396.

JoAnnes Chrysostomus, In Joannem hom. 1-88, PG 59, 23-482.

Joannes Chrysostomus, In Matthaeum hom. 1-90, PG 57, 13 - 58, 794, tłum. J. Krystyniacki (homilie 1-40 i 61-90) - A. Baron (homilie 41-60): Św. Jan Chryzostom, Homilie na Ewangelię wedtug św. Mateusza, oprac. A. Baron, t. 1-2, ŹMT 18, 23, Kraków 2000-2001.

JoAnnes Chrysostomus, In paralyticum demissum per tectum, PG 51, 47-64.

Palladius, Dialogus de vita Iohannis Chrysostomi, ed. A.M. Malingrey - P. Leclercq, SCh 341, Paris 1988.

Socrates, Historia ecclesiastica, ed. G.C. Hansen, GCSNF 1, Berlin 1995.

Synaxarium ecclesiae Constantinopolitanae e codice Sirmondiano nunc Berolinensi, ed.

H. Delehaye, w: Propylaeum ad Acta sanctorum Novembris, Bruxellis 1902.

\section{Opracowania}

Allen P. - Mayer W., Computer and Homily: Accessing the Everyday Life of Early Christians, VigCh, 47 (1993) 260-280.

Allen P. - Neil B. - Mayer W., Reading the Texts: A Methodology of Approach to Genre, w: Preaching Poverty in Late Antiquity: Perceptions and Reality, ed. P. Allen - B. Neil - W. Mayer, Arbeiten zur Kirchen- und Theologiegeschichte 28, Leipzig 2009, 36-68.

Baldovin J.F., The Urban Character of Christian Worship The Origins, Development and Meaning of Stational Liturgy, OCA 228, Rome 1987.

BAur C., Johannes Chrysostomus und seine Zeit, t. 1: Antiochien, München 1929.

Berthold H., Frühe christliche Literatur als Quelle fur Sozialgeschichte, w: Das Korpus der Griechischen Christlichen Schriftsteller: Historie, Gegenwart, Zukunft, hrsg. von J. Irmscher - K. Treu, TU 120, Berlin 1977, 43-63.

Brottier L., Introduction, w: Jean Chrysostome, Sermons sur La Genèse, SCh 433, Paris 1998, 11-70.

Brown P., Poverty and Leadership in the Later Roman Empire, Hanover - London 2002.

Clavis Patrum Graecorum, vol. 2: Ab Athanasio ad Chrysostomus, cura et studio M. Geerard, Turnhout 1974.

Cunningham M.B., Preaching and the Community, w: Church and People in Byzantium, Society for the Promotion of Byzantine Studies Twentieth Spring Symposium of Byzantine Studies, Manchester 1986, ed. R. Morris, Birmingham 1990, 29-46. 
Dagron G., Naissance d'une capitale. Constantinople et ses institutions de 330 à 451, Paris 1974.

De l'homélie au sermon. Histoire de la prédication médiévale, éd. J. Hamesse - X. Hermand, Publications de l'Institut d'Études Médiévales. Textes, Études, Congrès 14, Louvain-la-Neuve 1993.

De ore Domini. Preacher and the Word in the Middle Ages, ed. T.L. Amos - E.A. Green B. Mayne Kienzle, Studies in Medieval Culture 27, Kalamazoo 1989.

FInN R., Almsgiving in the Later Roman Empire: Christian Promotion and Practice (313450), Oxford 2008.

Gapp K.S., The Universal Famine Under Claudius, HTR 28 (1935) 258-265.

Garnsey P., Famine and Food Supply in the Graeco-Roman World, Cambridge 1988.

Garnsey P., Food and Society in Classical Antiquity, Cambridge 1999.

Garnsey P., Responses to Food Crisis in the Ancient Mediterranean World, w: Hunger in History: Food Shortage, Poverty and Deprivation, ed. L.F. Newman, Cambridge (Mass.) 1990, 126-146.

Hamman A., Dogmatik und Verkündigung in der Väterzeit, „Theologie und Glaube” 61 (1971) 109-140 i 202-231.

Holman S.R., Constructed and Consumed: The Everyday Life of the Poor in $4^{\text {th }} C$. Cappadocia, w: Social and Political Life in Late Antiquity, ed. W. Bowden - A. Gutterdige - C. Machado, Late Antique Archaeology 3, Leiden 2006, 441-464.

Holman S.R., The Hungry are Dying: Beggars and Bishops in Roman Cappadocia, Oxford - New York 2001.

Holman S.R., The Hungry Body: Famine, Poverty, and Identity in Basil's Hom. 8, JECS 7 (1999) 337-363.

Jameson M., Famine in the Greek World, w: Trade and Famine in Classical Antiquity, ed. P. Garnsey - C.R. Whittaker, Cambridge Philological Society. Supplementary Volumes 8, Cambridge 1983, 6-16.

KaczYnski R., Das Wort Gottes in Liturgie und Alltag der Gemeinden des Johannes Chrysostomus, Freiburger Theologische Studien 94, Freiburg im Breisgau - Basel - Wien 1974.

Kelly J.N.D., Golden Mouth. The Story of John Chrysostom - Ascetic, Preacher, Bishop, Ithaca - New York 1998 = Złote usta. Jan Chryzostom - asceta, kaznodzieja, biskup, thum. K. Krakowczyk, Bydgoszcz 2001.

Konstantynopol - Nowy Rzym: miasto i ludzie w okresie wczesnobizantyńskim, red. M.J. Leszka - T. Wolińska, Warszawa 2011.

LeYerle B., John Chrysostom on Almsgiving and the Use of Money, HTR 87 (1994) 29-47.

Liebeschuetz J.H.W.G., The Finances of Antioch in the Fourth Century A. D., ByZ (1959) 344-356.

MacMullen R., The preacher's audience (AD 350-400), JTS 40 (1989) 503-511.

Mayer W., John Chrysostom on Poverty, w: Preaching Poverty in Late Antiquity: Perceptions and Reality, ed. P. Allen - B. Neil - W. Mayer, Arbeiten zur Kirchen- und Theologiegeschichte 28, Leipzig 2009, 69-118.

Mayer W., Poverty and Society in the World of John Chrysostom, w: Social and Political Archaeology in Late Antiquity, ed. L. Lavan - W. Bowden - A. Gutteridge - C. Machado, Late Antique Archaeology 3, Leiden 2006, 465-484.

Mayer W., The Homilies of St John Chrysostom: Provenance. Reshaping the Foundations, OCA 273, Rome 2005.

Millman S.W. - Kates R.W., Toward Understanding Hunger, w: Hunger in History: Food Shortage, Poverty and Deprivation, Cambridge (Mass.) 1990, 3-24. 
Müller C.D.G., Einige Bemerkungen zur «ars praedicandi» der alten koptischen Kirche, „Muséon” 67 (1954) 231-270.

Olivar A., La predicación christiana antigua, Biblioteca Herder, Sección de teología y filosofía 189, Barcelona 1991.

PAVERD F. VAN DE, Zur Geschichte der Messliturgie in Antiocheia und Konstantinopel gegen Ende des vierten Jahrhunderts, OCA 187, Rome 1970.

Petropoulos J.C.B., The Church Father as Social Informant St John Chrysostom on folk-songs, StPatr 23 (1989) 159-164.

Rathbone D., The Grain Trade and Grain Shortages in the Hellenistic East, w: Trade and Famine in Classical Antiquity, ed. P. Garnsey - C.R. Whittaker, Cambridge Philological Society. Supplementary Volumes 8, Cambridge 1983, 45-55.

Salzmann J.C., Lehren und Ermahnen. Zur Geschichte des christlichen Wortgottesdienstes in den ersten drei Jahrhunderten, Wissenschaftliche Untersuchungen zum Neuen Testament, 2. Reihe, 59, Tübingen 1994.

Stander H., Chrysostom on Hunger and Famine, „Hervomde Teologies Studies” 67 (2011) 1-7.

Stathakopoulos D.Ch., Famine and Pestilence in the Late Roman and Early Byzantine Empire: A Systematic Survey of Subsistence Crises and Epidemics, Birmingham Byzantine and Ottoman Monographs 9, Aldershot 2004.

StrojnowsKi J., Głód, EK V 1143-1143.

Strojnowski J., Głód, I. Aspekt biologiczno-medyczny, EK V 1144.

Strzeszewski C., Gtód, II. Aspekt społeczno-ekonomiczny, EK V 1144-1146.

Szczur P., Problematyka społeczna w późnoantycznej Antiochii na podstawie nauczania homiletycznego Jana Chryzostoma, Lublin 2008.

Tiersch C., Johannes Chrysostomus in Konstantinopel (398-404). Weltsicht und Wirken eines Bischofs in der Hauptstadt des Oströmischen Reiches, Studien und Texte zu Antike und Christentum 6, Tübingen 2002.

Trade and Famine in Classical Antiquity, ed. P. Garnsey - C.R. Whittaker, Cambridge Philological Society. Supplementary Volumes 8, Cambridge 1983.

Virlouvet C., Famines et émeutes à Rome des origines de la République à la mort de Néron, Collection de l'École Française de Rome 87, Rome 1985.

Wilken R.L., John Chrysostom and the Jews. Rhetoric and Reality in the Late Fourth Century, Berkeley - Los Angeles - London 1983.

Winter B.W., Secular and Christian Responses to Corinthian Famines, ,Tyndale Bulletin" 40 (1989) 86-106. 